\title{
The Eyjafjöll explosive volcanic eruption from a microwave weather radar perspective
}

\author{
F. S. Marzano ${ }^{1,2}$, M. Lamantea ${ }^{1}$, M. Montopoli ${ }^{2,3}$, S. Di Fabio ${ }^{2,4}$, and E. Picciotti ${ }^{4}$ \\ ${ }^{1}$ Department of Information Engineering, Sapienza University of Rome, Rome, Italy \\ ${ }^{2}$ Centre of Excellence CETEMPS, University of L'Aquila, L'Aquila, Italy \\ ${ }^{3}$ Department of Electrical and Information Engineering, University of L'Aquila, Italy \\ ${ }^{4}$ HIMET, L'Aquila, Italy
}

Received: 12 March 2011 - Published in Atmos. Chem. Phys. Discuss.: 20 April 2011

Revised: 11 August 2011 - Accepted: 22 August 2011 - Published: 16 September 2011

\begin{abstract}
The sub-glacial Eyjafjöll explosive volcanic eruptions of April and May 2010 are analyzed and quantitatively interpreted by using ground-based weather radar data and the Volcanic Ash Radar Retrieval (VARR) technique. The Eyjafjöll eruptions have been continuously monitored by the Keflavík C-band weather radar, located at a distance of about $155 \mathrm{~km}$ from the volcano vent. Considering that the Eyjafjöll volcano is approximately $20 \mathrm{~km}$ from the Atlantic Ocean and that the northerly winds stretched the plume toward the mainland Europe, weather radars are the only means to provide an estimate of the total ejected tephra. The VARR methodology is summarized and applied to available radar time series to estimate the plume maximum height, ash particle category, ash volume, ash fallout and ash concentration every 5 min near the vent. Estimates of the discharge rate of eruption, based on the retrieved ash plume top height, are provided together with an evaluation of the total erupted mass and volume. Deposited ash at ground is also retrieved from radar data by empirically reconstructing the vertical profile of radar reflectivity and estimating the near-surface ash fallout. Radar-based retrieval results cannot be compared with ground measurements, due to the lack of the latter, but further demonstrate the unique contribution of these remote sensing products to the understating and modelling of explosive volcanic ash eruptions.
\end{abstract}

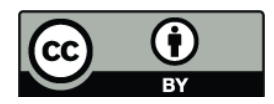

Correspondence to: F. S. Marzano (marzano@diet.uniroma1.it)

\section{Introduction}

The early detection and quantitative retrieval of volcanic ash clouds is both a scientific and practical issue which can have significant impacts on human activities. Volcanic eruptions can represent a serious socio-economic and a severe environmental hazard (Graf et al., 1999; Durant et al., 2010). Plume height, reaching typical altitudes of modern aerial routes, can affect flight safety and have huge knock-on effects on air traffic control, making necessary the re-routing of airways (Prata and Tupper, 2009). The volcanic eruptions may have both short-term effects, regarding health threats to people living in the area near the volcano, and long-term effects, since airborne ash clouds may affect both surface ocean biogeochemical cycles and control atmospheric feedbacks of climate trend (Robock, 2000; Duggen et al., 2010).

The previously described risk scenario has become unfortunately a reality in the spring 2010 during the last Eyjafjöll volcanic eruption which was the largest explosive eruption in Iceland since that of the Hekla volcano in 1947 (Petersen, 2010). The 2010 Eyjafjöll eruption featured both an initial phreato-magmatic phase (characterized by the presence of juvenile clasts, resulting from the interaction between magma and water) and predominantly magmatic remaining phases (Guðmundsson et al., 2010). Unlike previous Icelandic events, the 2010 Eyjafjöll eruption lasted several weeks, sustaining an average magma discharge of several hundred tonnes per second and producing large quantities of lapilli, coarse, fine and very fine ash particles which were advected towards south and south-east along the major European air traffic routes, causing an unprecedented flight crisis (Gertisser, 2010).

A quantitative measurement and analysis of volcanic ash cloud physical and chemical properties is crucial (Durant et al., 2010). Any decision support system for both civil

Published by Copernicus Publications on behalf of the European Geosciences Union. 
protection and air traffic management needs not only a detection of the erupted and dispersed ash cloud, but also the estimation and forecast of its ash content (Prata and Tupper, 2009). The Eyjafjöll eruption on 2010 has been one of the best documented European volcanic events in terms of ground and satellite observations (e.g., Ansmann et al., 2010; Bennet et al., 2010; Flentje et al., 2010; Gasteiger et al., 2011; Guðmundsson et al., 2010; Madonna et al., 2010; Mona et al., 2010; Schumann et al., 2011; Pietruczuk et al., 2010; Stohl et al., 2011). Particular importance is devoted to the "near-source" (where the "source" is the volcano vent) instrumentation as measured data can be used to properly initialized ash-plume dispersion models (e.g., Bonadonna et al., 2009; Costa et al., 2006; Stohl et al., 1998). Coarse ash and lapilli are expected to fall within few hours from ejection time into air and within distances less than few hundreds of kilometres from the volcanic vent (Rose and Durant, 2009). This deposited tephra (i.e., the fragmental material produced by a volcanic eruption) is typically estimated to be more than $99 \%$ of the total ash mass (Wen and Rose, 1994). Advanced volcanic sites can deal with an ensemble of "near-source" synergetic instruments (Sparks et al., 1997; Zehner, 2010): in situ drillings and sondes, surveillance flights for plume monitoring, GNSS (Global Navigation Satellite System) differential receivers for deformation measurements, seismic signal receivers for tremor analysis, interferometric synthetic aperture radars (InSARs) for deformation imaging, ground-based lidars, ceilometers, photometers and microwave radars for plume probing, very-lowfrequency (VLF) receivers for lightning detection and satellite infrared radiometers for broadscale plume tracking. Even Unmanned airborne vehicles (UAVs) cannot be used to probe the near-source tephra due to inherent risks (Schumann et al., 2011). Satellite visible and thermal infrared split-window techniques may miss "near-source" tephra as they are basically insensitive to ash particles larger than few tens of microns (Yu et al., 2002; Pavolonis et al., 2006; Kahn et al., 2007; McCarthy et al., 2008; Stohl et al., 2010). On the other hand, ground-based optical "near-source" observations may be completely opaque due to the strong extinction of coarse and large ash particles (Zehner, 2010).

"Near-source" observations, if available, do not generally include estimates on the ash plume volume and concentration. The magma discharge estimate is primarily based on an empirical relationship established between observed eruption column heights, derived from ground-based weather radars, and magma discharge (Lacasse et al., 2004; Oddsson et al., 2009). Estimates on concentration of ash solid material in the eruption plume are usually based on theoretical assumptions, which may be supported by satellite-based observations of the ash cloud at mid to far distances (hundreds of kilometres) from the vent (Wilson, 1972; Sparks et al., 1997). In this context active microwave remote sensing, through ground-based scanning weather radars, can be better exploited and can represent a very powerful, and to some extent, unique instrument to study explosive eruptions in proximity of volcanic vents (Harris and Rose, 1983; Lacasse et al., 2004; Marzano et al., 2006a; Gouhier and Donnadieu, 2008). In the "near-source" region weather radars may be capable to provide, in principle, not only the plume height, but also ash particle category, ash volume, ash fallout and ash concentration (Marzano et al., 2006b, 2010b, 2011a). Conventional weather radar targets are precipitating hydrometeors whose shape, dimension and dielectric properties are undoubtedly different from tephra ones (Sauvageot, 1992). This implies that weather radars cannot be used for ash cloud monitoring without developing ad hoc inversion methodologies and techniques to process radar data stream. Among these algorithms, the VARR (Volcanic Ash Radar Retrieval) approach has been shown to be a relatively general theoretical and operational framework to infer, in a quantitative way, ash mass category, concentration and fallout rate from three-dimensional (3-D) scanning weather-radar measurements (Marzano et al., 2006b, 2010a). The VARR products must be carefully treated as, any remote sensing inversion methodology, they are obtained under proper physicalstatistical assumptions and given sensor limitations (e.g., receiver sensitivity and polarization agility).

The potential of VARR data processing in observing volcanic ash clouds, has been analyzed using some case studies where volcano eruptions happened near an available weather radar: (i) the Grímsvötn volcano eruption in 2004, analyzed together with the Icelandic Meteorological Office (IMO) using a C-band weather radar (Marzano et al., 2006b, 2010a, 2010b); (ii) the Augustine volcano eruption in 2006, analyzed together with the US Geological Survey Alaska Volcano Observatory using an S-band weather radar (Marzano et al., 2010b). This work presents new results of the VARR methodology, applied to the sub-glacial explosive eruptions of Icelandic Eyjafjöll stratovolcano, whose maximum activities occurred on April and May 2010. The 2010 eruptions have been monitored and measured by the Keflavík C-band weather radar at a distance of about $155 \mathrm{~km}$ from the volcano vent (Guðmundsson et al., 2010). The distance between the Eyjafjöll volcano and the Icelandic coast is approximately $20 \mathrm{~km}$. Due to the proximity between the volcano and the Atlantic Ocean and the prevailing northerly winds which stretched the plume toward the mainland $\mathrm{Eu}-$ rope, collecting ground data samples in order to estimate the total ejected tephra or the ash distribution is not an easy task, especially in the nearby of the Eyjafjöll volcano. In this respect weather radar is one of the most powerful instruments to investigate this phenomenon and estimate the near-source ash fallout.

This paper is structured as follows. In Sect. 2 the Eyjafjöll eruptions of April and May 2010 are described and the effects of the volcanic plume are summarized. Moreover, radar data are discussed and VARR algorithm data processing features are briefly introduced. In Sect. 3 weather radar retrievals with reference to time and spatial volcanic cloud 
products are presented, discussed and compared. Lastly, Sect. 4 is dedicated to conclusions and tracing future research and development perspectives.

\section{Data and methodology}

The Eyjafjöll stratovolcano is located under the Eyjafjallajökull ice cap, a small glacier within the Icelandic East Volcanic Zone (Larsen et al., 1998; Pedersen and Sigmundsson, 2006). The latter is the most active of the four Icelandic volcanic zones due to its position over the Mid-Atlantic Ridge, the divergent tectonic plate boundary between the Eurasian Plate and the North American Plate (Thordarson and Larsen, 2007). The eruptions in 2010 lasted several weeks, starting at the end of March with precursors event (such as seismic activities) since the end of 2009; on April 2010 and May 2010 the activity of the volcano reached its peak levels, with some explosive eruptions (Guðmundsson et al., 2010; Petersen, 2010).

\subsection{Volcanic eruptions on April and May, 2010}

The Eyjafjöll eruptions in 2010 were preceded by seismic activities around December 2009 that increased at the end of February 2010 (Guðmundsson et al., 2010). These earthquakes were followed by the first magma pourings into the magma chamber of the volcano. In the first phase of the eruption, from 20 March to 1 April, some fissures opened in Fimmvörðuháls (on the eastern flank of Eyjafjöll volcano) over the glacial ice. The eruption was rated, through the volcanic explosivity index (VEI, a relative logarithmic measure of the explosiveness of volcanic eruptions with value 0 for non-explosive eruptions and 8 for colossal ones), as VEI 1 due to the effusive, sub-glacial and weak volcanic activities and was precursory with respect to the second, more significant, eruption phase. The latter lasted from 14 April until 20 May and was rated VEI 4, thus being 40 times more powerful than the first phase (Guðmundsson et al., 2010).

On 14 April at 06:00 UTC, the Eyjafjöll volcano resumed erupting after a small hiatus; due to the main eruption site position under the centre of the glacier, the eruption became explosive and phreatomagmatic (Guðmundsson et al., 2010; Petersen, 2010). People living and working in the nearby areas were evacuated, in order to avoid potentially lethal encounters with the released glacier burst (or jökulhlaup, in Icelandic) and the large-scale discharge of melt water reaching the sand on the lowland plains (or sandur) to the north of the volcano. On 15 April, the ash cloud reached mainland Europe, thus forcing the closure of airspace over a large part of the United Kingdom, Scandinavia and Northern Europe. The eruption tremors continued at a similar level to those observed immediately before the start of the second eruption phase. On 16 and 17 April, a pulsating eruptive column reached above $8 \mathrm{~km}$ altitude, with a maximum of $13 \mathrm{~km}$ be- fore the plume height decreasing to $5 \mathrm{~km}$ that was too low to let it travel across Europe. On 18 April, the seismic activities continued, but the eruption further decreased (dropped by an order of magnitude) becoming magmatic (implying that external water no longer had ready access to the vents), with a maximum plume until 08:00 UTC lower than $3 \mathrm{~km}$ as recorded by the IMO. On 19 April the Eyjafjöll started to erupt lava flows that slowly melted their way through the ice of the Gígjökull outlet glacier and the plume reached again an altitude of $5 \mathrm{~km}$, spreading to south direction due to northerly winds. On 20 April, the GPS stations around Eyjafjallajökull showed a deflation associated with the eruption. In the following nine days, the eruption became discontinuous with increasing and decreasing tremors activities as reported by the IMO, and the ash plume rose up to few kilometres (often not exceeding the height of the cloud cover at about $5 \mathrm{~km}$ altitude) with mild explosive activity and light ash fall. During these first two weeks, continued, widespread and unprecedented disruption to flights and closure of some airports occurred both in Iceland and many European countries (Gertisser, 2010).

On the beginning of May, a lava producing phase larger than the explosive phase started. Plume became darker, denser and wider than in the preceding week, with an increased tephra fall out near the volcano and an eruption plume extended to altitudes between $4 \mathrm{~km}$ and $6 \mathrm{~km}$ (Guðmundsson et al., 2010; Petersen, 2010). On 5 and 6 May, IMO stated that the volcano had entered a new phase with a shift back from lava to more ash production. An increase in explosive activity and considerable ash fall out was reported at a distance of about $70 \mathrm{~km}$ from the eruption site. Plumes were observed at altitudes between $5.5 \mathrm{~km}$ and $6.5 \mathrm{~km}$, reaching a maximum height of $9 \mathrm{~km}$. On 7 and 8 May, the eruption was still in a strong explosive phase although its explosive activity decreased compared to the previous days: the ash plume was rising to a lower altitude and was lighter in color. On 9 May, the ash cloud reached its stretching maximum. In northern Spain (2000 km from Iceland) and other western European countries (Ireland, France and Portugal), the ash cloud forced several airports closures. On 10 May the ash cloud rose up to between $5 \mathrm{~km}$ and $6 \mathrm{~km}$ (with some finer particles rising up to $9 \mathrm{~km}$ ) and in the following days it became darker and was headed in a south-easterly direction. Since 21 May, the eruptive vent emitted a column of steam (water vapour) plus sulphurous gases with an eruption column confined mostly in the proximity of the crater; no further report of any ash fall from the surrounding area have been registered. This phase of low activity and quiet state of the eruption was officially declared over on October. 


\subsection{C-band weather radar data}

Weather radar systems, although designed to study hydrometeors and rain clouds, can be used to monitor and measure volcanic eruptions parameters (Harris and Rose, 1983; Marzano et al., 2006a). The measured radar backscattered power, from a volume bin at range $r$, zenith angle $\theta$ and azimuth angle $\phi$, is proportional to the co-polar horizontallypolarized reflectivity factor $Z_{\mathrm{H}}\left(\mathrm{mm}^{6} \mathrm{~m}^{-3}\right)$, which is expressed for an ensemble of spherical particles under the Rayleigh scattering assumption (Sauvageot, 1992):

$Z_{\mathrm{H}}(r, \theta, \varphi)=\frac{\lambda^{4}}{\pi^{5}\left|K_{\varepsilon}\right|^{2}} \eta_{\mathrm{H}}(r, \theta, \varphi) \cong \int_{D_{1}}^{D_{2}} D^{6} N_{a X}(D) d D=m_{6}$

where $\lambda$ is radar wavelength, $K_{\varepsilon}$ is the particle dielectric factor (depending on its composition), $\eta_{\mathrm{H}}$ is the horizontallypolarized reflectivity, $D$ is the equivolume spherical particle diameter, $N_{a X}$ is the particle size distribution (PSD) and $m_{6}$ is the PSD sixth moment. The latter can be modelled as Scaled Gamma $(X=\mathrm{SG})$ or Scaled Weibull PSD $(X=\mathrm{SW})$, characterized by 3 parameters: the particle-number mean diameter $D_{\mathrm{n}}(\mathrm{mm})$, the ash concentration $C_{\mathrm{a}}\left(\mathrm{g} \mathrm{m}^{-3}\right)$ and the PSD shape coefficient $\mu$ (Marzano et al., 2006a; Sparks et al., 1997). From Eq. (1), keeping constant the ash particle distribution, the reflectivity factor $Z_{\mathrm{H}}$ tends to be higher for bigger particles. It is worth noting that the last approximation is not always valid as particle Mie backscattering effects may need to be taken into consideration depending on the ash cloud formation and the radar wavelength (Sauvageot, 1992; Marzano et al., 2006a). The measured reflectivity factor $Z_{\mathrm{Hm}}$ can be simulated from the theoretical one $Z_{\mathrm{H}}$ in Eq. (1) by introducing instrumental and model representativeness errors, the latter being usually modelled as a multiplicative zero-mean Gaussian noise (in linear units). Note that dual-polarization weather radars can offer the potential to measure not only $Z_{\mathrm{H}}$, but also vertically-polarized reflectivity and differential phase shift which may be useful to better characterize ash particle properties and non-spherical shape (Marzano et al., 2011b). Weather radar volume samples, as in Eq. (1), are acquired by using discrete time and space steps. All radarbased retrieved geophysical parameters require the knowledge of data spatial and temporal resolution. Concerning the spatial resolution, the range bin size is proportional to the pulse width, whereas its transverse resolution quadratically increases with the radar range (Sauvageot, 1992). Temporal resolution is usually constant (here about $5 \mathrm{~min}$ ) so that $N_{\mathrm{S}}$ radar volume scan temporal samples are available with sampling time step $\Delta t_{\mathrm{s}}$, depending on the considered time interval.

The eruption was detected and monitored during its whole life span by the C-band $(6 \mathrm{GHz})$ weather radar in Keflavík, located $155-\mathrm{km}$ north-westwards far away from the caldera of Eyjafjöll volcano (e.g., Lacasse et al., 2004; Marzano et al., 2010b). The Keflavík C-band radar volumes were available from the IMO every $\Delta t_{\mathrm{s}}=5 \mathrm{~min}$ with reference to the two more significant time windows of the event: since 01:00 UTC (Universal Time Coordinated) on 14 April 2010 till 23:55 UTC on 20 April 2010 and since 00:10 UTC on 5 May 2010 till 23:55 UTC on 10 May 10 2010. Ten elevation angles were routinely available (specifically, $0.5^{\circ}, 0.9^{\circ}$, $1.3^{\circ}, 2.4^{\circ}, 3.5^{\circ}, 4.5^{\circ}, 6.0^{\circ}, 8.0^{\circ}, 10.0^{\circ}$ and $15.0^{\circ}$ ). The radar dataset consists of a total of $N_{\mathrm{s}}=3730$ volumes in spherical coordinates with 10 elevation angles, 420 azimuth angles and 120 range bins, the latter having a range width of about $2 \mathrm{~km}$.

Eight of the most significant Horizontal-Vertical Maximum Indicator (HVMI) recorded radar reflectivity images are shown in Fig. 1 with reference to the time window of April and Fig. 2 with reference to the time window of May. The maximum values of the detected reflectivity are projected on the surface as a PPI (Plan Position Indicator) georeferenced radial map (right-bottom panel) and projected on two orthogonal planes along the vertical (top and left side of the HVMI image). The ash plume is visible over the Eyjafjöll, especially by looking at the upper section (showing the north-south profile of the plume) and the left section (showing the east-west profile of the plume). The detected volcanic cloud is distinguishable from undesired ground clutter and rain cloud returns, especially when looking at the HVMI vertical sections. Ground clutter can be easily recognized from HVMI as it tends to be stationary from an image to another. On the contrary, precipitating clouds have a reflectivity signature quite similar to ash clouds and the mix of the two is difficult to treat. In the case of 2010 Eyjafjöll event the observed temporal sequence indicates a distinct ash feature erupted from the volcano vent which can be effectively detected.

\subsection{Weather radar data processing}

The VARR approach foresees 2 steps: (i) ash classification; (ii) ash estimation. Both steps are trained by a physicalelectromagnetic forward model, basically summarized by Eq. (1) where the main PSD parameters are supposed to be constrained random variables (Marzano et al., 2006b, 2010a). The generation of a simulated ash-reflectivity dataset by letting PSD parameters to vary in a random way, can be framed within the so called Monte Carlo techniques.

Automatic discrimination of ashes classes with respect to average diameter $<D_{\mathrm{n}}>$ and with respect to average concentration $<C_{\mathrm{a}}>$ implies the capability of classifying the radar volume reflectivity measurements into one of the $N_{c}$ classes. In order to optimize and adapt the retrieval algorithm to the Icelandic scenario, VARR has been statistically calibrated with ground-based ash size distribution samples, taken within the Vatnajökull ice cap in 2005 and 2006 after the Grímsvötn last eruption occurred in November 2004 (Oddsson et al., 2009), since ground PSD data from the Eyjafjöll eruption are still quite limited (e.g., Stohl et al., 2010). Optimal values of PSD parameters have been adopted 

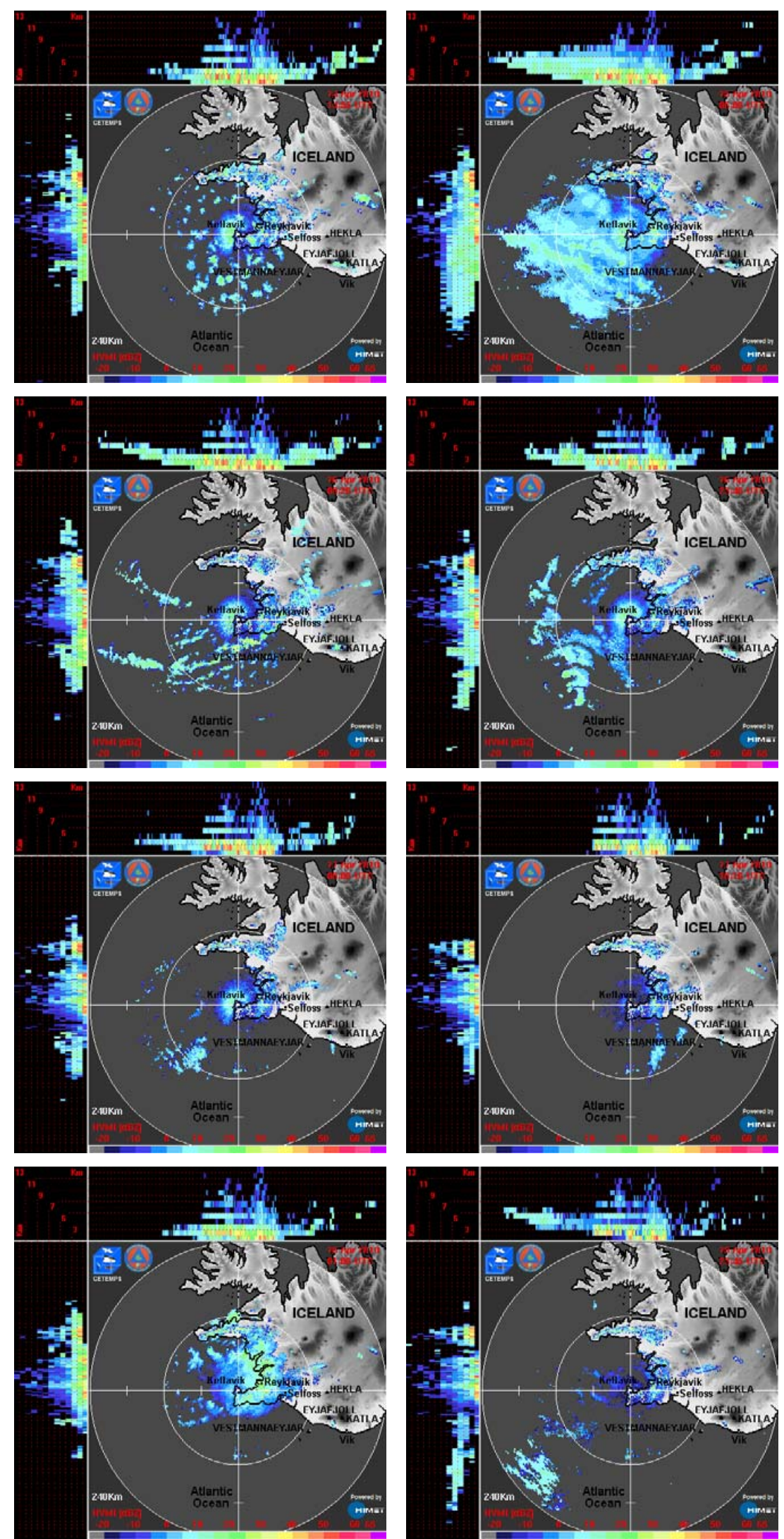

Fig. 1. Eight of the most significant HVMI radar images showing the recorded Keflavík C-band radar reflectivity from 14 April 2010 at 14:55 UTC till 19 April at 23:45 UTC. See text for details. 

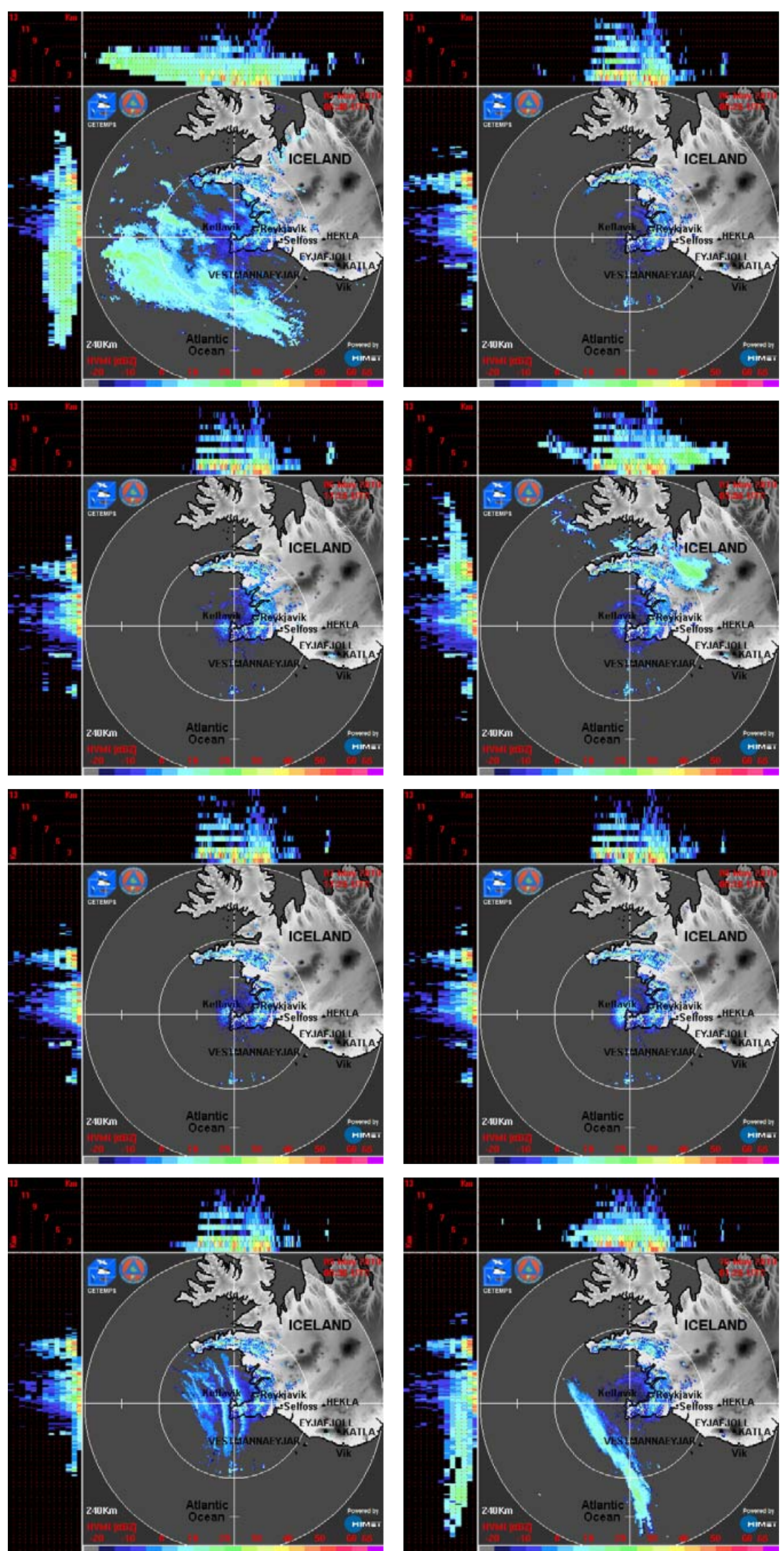

Fig. 2. Eight of the most significant HVMI radar images showing the recorded Keflavík C-band radar reflectivity from 5 May 2010 at 06:40 UTC till 10 May at 01:25 UTC. See text for details. 
through best fitting of SG-PSD and SW-PSD on measured PSD for each ash diameter class (Marzano et al., 2011a). In summary, within each of the $N_{c}=9$ ash classes we have supposed a Gaussian random distribution for: (i) $D_{\mathrm{n}}$ with average value $<D_{\mathrm{n}}>$ equal to $0.006,0.0641$ and $0.5825 \mathrm{~mm}$ for fine, coarse and lapilli ash, respectively, a standard deviation $\sigma_{D_{\mathrm{n}}}=0.2<D_{\mathrm{n}}>$ and a corresponding variability of $0.001 \leq D_{\mathrm{n}}<0.06 \mathrm{~mm}, 0.06 \leq D_{\mathrm{n}}<0.5 \mathrm{~mm}$, and $0.5 \leq$ $D_{\mathrm{n}} \leq 7.0 \mathrm{~mm}$; (ii) $C_{\mathrm{a}}$ with mean value $<C_{\mathrm{a}}>$ equal to 0.1 , 1 and $5 \mathrm{~g} \mathrm{~m}^{-3}$ for light, moderate and intense concentration regimes, respectively, and a standard deviation $\sigma_{\mathrm{Ca}}=0.5<$ $C_{\mathrm{a}}>$. The ash density $\rho_{\mathrm{a}}$ has been put equal to an average value of $1200 \mathrm{~kg} \mathrm{~m}^{-3}$. The optimal PSD shape parameter $\mu$ has been set to $0.9,1.1$ and 1.4 for fine, coarse and lapilli particles. Table 1 summarizes the modelled ash classes.

Within the VARR methodology, ash classification is performed by the use of the MAP (Maximum A Posteriori Probability) estimation (Marzano et al., 2006b). The probability density function (PDF) of each ash class $(c)$, conditioned to the measured reflectivity factor $Z_{\mathrm{Hm}}$ can be expressed through the Bayes theorem. The MAP estimation of ash class, $c$, corresponds to the maximization with respect to $c$ of the posterior PDF $p\left(c \mid Z_{\mathrm{Hm}}\right)$. Under the assumption of multivariate Gaussian PDFs, the previous maximization reduces to the following minimization which provides an ash class for a given volume bin centred in $(r, \theta, \varphi)$ :

$\hat{c}(r, \theta, \varphi)=\operatorname{Min}_{c}\left\{\frac{\left[Z_{\mathrm{Hm}}(r, \theta, \varphi)-m_{Z}^{(c)}\right]^{2}}{\left(\sigma_{Z}^{(c)}\right)^{2}}+\ln \left(\sigma_{Z}^{(c)}\right)^{2}-2 \ln p[c(r, \theta, \varphi)]\right\}$

where $\operatorname{Min}_{c}$ is the minimum value with respect to $c, m_{Z}^{(c)}$ and $\sigma_{Z}^{(c)}$ are the reflectivity mean and standard deviation of class $c$, whereas $p(c)$ is the a priori PDF of class $c$ and the ash class perturbations have been assumed uncorrelated. Computing Eq. (2) requires knowledge of the reflectivity mean $\left(m_{Z}^{(c)}\right)$ and standard deviation $\left(\sigma_{Z}^{(c)}\right)$ of each ash class, $c$, derived from the 9-class simulated synthetic data set, previously described.

For each radar volume bin, the ash fallout rate $R_{\mathrm{a}}$ $\left(\mathrm{kg} \mathrm{m}^{-2} \mathrm{~s}^{-1}\right)$ and ash concentration $C_{\mathrm{a}}\left(\mathrm{g} \mathrm{m}^{-3}\right)$ can be theoretically expressed by:

$$
\left\{\begin{array}{l}
R_{\mathrm{a}}=\int_{D_{1}}^{D_{2}} v_{\mathrm{a}}(D) m_{\mathrm{a}}(D) N_{a X}(D) d D \\
C_{\mathrm{a}}=\int_{D_{1}}^{D_{2}} m_{\mathrm{a}}(D) N_{a X}(D) d D
\end{array}\right.
$$

where $v_{\mathrm{a}}(D)$ is the terminal ashfall velocity in still air (when the vertical component of the air speed is neglected) and $m_{\mathrm{a}}$ is the actual ash mass particle (typically approximated by an equivolume sphere). A power-law dependence of $v_{\mathrm{a}}$ on $D$ is usually assumed in Eq. (3), e.g. $v_{\mathrm{a}}=a_{v} D^{b_{v}}$, as shown in Marzano et al. (2006b): from Harris and Rose (1983) the best fitting provides $a_{v}=5.558 \mathrm{~m} \mathrm{~s}^{-1}$ and $b_{v}=0.722$, whereas from Wilson (1972) $a_{v}=7.460 \mathrm{~m} \mathrm{~s}^{-1}$ and $b_{v}=1.0$.
The inversion problem to retrieve $C_{\mathrm{a}}$ and $R_{\mathrm{a}}$ from $Z_{\mathrm{Hm}}$ is ill-posed so that it can be statistically approached (Marzano et al., 2006b). Through the training forward model, as in Eq. (1), a regressive approximation may be used as a function of the class $c$ for both $C_{\mathrm{a}}$ and $R_{\mathrm{a}}$ for a given volume bin centred in $(r, \theta, \varphi)$ :

$$
\left\{\begin{array}{l}
R_{\mathrm{a}}^{(c)}(r, \theta, \varphi)=c_{c} Z_{\mathrm{Hm}}^{d_{c}}(r, \theta, \varphi) \\
C_{\mathrm{a}}^{(c)}(r, \theta, \varphi)=a_{c} Z_{\mathrm{Hm}}^{b_{c}}(r, \theta, \varphi)
\end{array}\right.
$$

where $Z_{\mathrm{Hm}}$ is the measured reflectivity factor and $a_{c}, b_{c}, c_{c}$ and $d_{c}$ are the regression coefficients, derived from simulated training dataset.

Sensitivity of weather radar observations to ash size and concentration is dependent on the transmitted wavelength and receiver Minimum Detectable Signal (MDS), which in turn is quadratically dependent on the inverse range (Sauvageot, 1992; Marzano et al., 2006b). Numerical analysis has shown that intense concentration of fine ash (about $5 \mathrm{~g} \mathrm{~m}^{-3}$ of average diameter of $0.01 \mathrm{~mm}$ ) can be detected by a typical C-band radar $50 \mathrm{~km}$ far from the ash plume, whereas smaller concentrations are not usually retrieved (Marzano et al., 2006b). This limitation may be overcome, for the same transmitted power, by either reducing the range or increasing the receiver sensitivity or decreasing the wavelength or radially averaging data. Another major problem is the incapability to discriminate between pure ash particles and aggregates of ash and hydrometeors (such as cloud ice and water) using single-polarization radar data only, as evident from Figs. 1 and 2. Apart from the use of a priori information, such as the freezing level and satellite-based imagery which are not always available (Marzano et al., 2010b), we can take into account these effects only as a larger uncertainty within the modelled Gaussian noise with a total standard deviation of $2.4 \mathrm{dBZ}$. A more robust VARR inversion algorithm will exhibit, of course, a larger estimate error variance.

\section{Ash cloud retrieval}

The VARR technique can be applied to each radar resolution volume in three-dimensional (3-D) spherical coordinates where the measured $\mathrm{C}$-band reflectivity, $Z_{\mathrm{Hm}}(r, \theta, \phi)$, is larger than the minimum detectable reflectivity (MDZ), as discussed in Marzano et al. (2006b, 2010a). From the Keflavík radar specifications, at a range of about $155 \mathrm{~km}$ which corresponds to the Eyjafjöll volcano vent, MDZ is about $-6 \mathrm{dBZ}$. From the mentioned analyses, this MDZ implies that radar echoes are sensitive to coarse ash and lapilli concentration, but not necessarily to moderate and light $\left(<5 \mathrm{~g} \mathrm{~m}^{-3}\right)$ fine ash distribution (Marzano et al., 2006b, 2010a). 
Table 1. Ash classes features in terms of average ash diameter $<D_{\mathrm{n}}>$ and concentration $<C_{\mathrm{a}}>$. The variability within each class is Gaussian with a deviation proportional to the mean, $\sigma_{D_{\mathrm{n}}}=0.2<D_{\mathrm{n}}>$ and $\sigma_{\mathrm{Ca}}=0.5<C_{\mathrm{a}}>$.

\begin{tabular}{cccc}
\hline ASH CLASSES & $\begin{array}{c}\text { Light concentration } \\
<C_{\mathrm{a}}>=0.1 \mathrm{~g} \mathrm{~m}^{-3}\end{array}$ & $\begin{array}{c}\text { Moderate concentration } \\
<C_{\mathrm{a}}>=1.0 \mathrm{~g} \mathrm{~m}^{-3}\end{array}$ & $\begin{array}{c}\text { Intense concentration } \\
<C_{\mathrm{a}}>=5.0 \mathrm{~g} \mathrm{~m}^{-3}\end{array}$ \\
\hline Fine ash size & FA-LC & FA-MC & $c=2$ \\
$<D_{\mathrm{n}}>=0.006 \mathrm{~mm}$ & $c=1$ & $\begin{array}{c}\text { FA-IC } \\
c=3\end{array}$ \\
\hline Coarse ash size & CA-LC & FA-MC & CA-IC \\
$<D_{\mathrm{n}}>=0.064 \mathrm{~mm}$ & $c=4$ & $c=5$ & $c=6$ \\
\hline Lapilli particle size & LP-LC & LP-MC & LP-IC \\
$<D_{\mathrm{n}}>=0.583 \mathrm{~mm}$ & $c=7$ & $c=8$ & $c=9$ \\
\hline
\end{tabular}

Only PPIs at the first 7 available elevation angles (i.e., $0.5^{\circ}, 0.9^{\circ}, 1.3^{\circ}, 2.4^{\circ}, 3.5^{\circ}, 4.5^{\circ}$ and $6.0^{\circ}$ ) have been used, as the other ones were useless since radar beam heights did not intercept the ash plume at higher elevations (see Figs. 1 and 2). Raw reflectivity data were averaged to about $2-\mathrm{km}$ radial resolution in order to enhance the signal-to-noise ratio and thus reduce the MDZ. The VARR products in terms of ash concentration $C_{\mathrm{a}}$ and fallout $R_{\mathrm{a}}$ are originally provided within 3-D spherical coordinates $(r, \theta, \phi)$ reference system. Radar returns have then been geo-located into a new reference system $(\lambda, \varphi, z)$ where $\lambda$ is the longitude, $\varphi$ is the latitude and $z$ terrain height. Spherical coordinates have been converted into longitude and latitude through the inversion of the "haversine" formula, used to compute the great-circle distance (i.e. the shortest distance over the surface of the Earth) between two points:

$\varphi=\frac{180}{\pi}\left[\operatorname{asin}\left(\sin \left(\varphi_{\mathrm{R}}\right) \cos \left(\frac{r}{R_{\mathrm{e}}}\right)\right)+\cos \left(\varphi_{\mathrm{R}}\right) \sin \left(\frac{r}{R_{\mathrm{e}}}\right) \cos (\phi)\right]$

$\lambda=\frac{180}{\pi}\left[\lambda_{\mathrm{R}} \frac{180}{\pi}+\operatorname{atan} 2\left(\sin (\phi) \sin \left(\frac{r}{R_{\mathrm{e}}}\right) \cos \left(\varphi_{\mathrm{R}}\right), \cos \left(\frac{r}{R_{\mathrm{e}}}\right)-\sin (\varphi) \sin \left(\varphi_{\mathrm{R}}\right)\right)\right]$

where $\lambda_{\mathrm{R}}$ (decimal deg) and $\varphi_{\mathrm{R}}$ (decimal deg) are the Keflavík radar longitude and latitude in decimal degrees (respectively, $-22.64^{\circ}$ and $64.03^{\circ}$ ), asin is the arcsine function, atan 2 is the four quadrant inverse tangent (arctangent) function and $180 / \pi$ converts radians into decimal degrees. Supposing a standard atmosphere for electromagnetic waves propagation, the terrain altitude $z$ can be derived by:

$z=\sqrt{r^{2}+R_{\mathrm{e}}^{2}+2 r R_{\mathrm{e}} \sin (\theta)}-R_{\mathrm{e}}+z_{\mathrm{R}}$

where $z_{\mathrm{R}}(\mathrm{m})$ is the radar height above sea level $(47 \mathrm{~m}$ in our case) and $R_{\mathrm{e}}=(4 / 3) R_{T}$ is the equivalent Earth radius, given by the so called " $4 / 3$ refraction model", where $R_{T}(\mathrm{~km})$ is the Earth radius (Sauvageot, 1992). The Eq. (6) states that the radar beam height is range and elevation angle dependent: when $r$ and $\theta$ increase, the detected altitudes increase so that only some of the elevation angles can be used due to the large radar-volcano distance and the expected maximum plume heights. A finer grid $(\lambda, \varphi, z)$ has been generated in order to allow an easier data geolocation.

\subsection{Retrieval time series}

The instantaneous volcanic ash cloud volume $V_{\mathrm{a}}(t)\left(\mathrm{m}^{3}\right)$, which represents the volume of the ash cloud at a given time step $t$ (the latter is referred to as "instantaneous" even though the radar employs about 2 minutes to complete a volume scan), may be estimated by using a threshold $C_{\text {ath }}$ on the estimated concentration $C_{\mathrm{a}}(\lambda, \varphi, z ; t)$ at a given position $(\lambda, \varphi$, z) as follows:

$V_{\mathrm{a}}(t) \equiv \int_{C_{\mathrm{a}}(\lambda, \phi, z ; t) \geq C_{\mathrm{ath}}} d V$

where $d V\left(\mathrm{~m}^{3}\right)$ is the elementary volume. The radar-derived total volume $V_{\mathrm{aT}}\left(\mathrm{m}^{3}\right)$ can then be computed by integrating $V_{\mathrm{a}}(t)$ with respect to the initial and final time steps of the volcanic eruption.

The instantaneous volume $V_{\mathrm{a}}(t)$ in (7) should be, indeed, distinguished into the "detected" volume $V_{\mathrm{ad}}(t)$ and a "hidden" (non-detected) volume $V_{\text {ah }}(t)$ (e.g., see Figs. 1 and 2). In general $V_{\mathrm{a}}(t)=V_{\mathrm{ad}}(t)+V_{\mathrm{ah}}(t)$ due to the radar observation geometry and the presence of occlusions along the ray paths. The term $V_{\text {ah }}$ implies that the total portion of the ash cloud $V_{\mathrm{a}}(t)$ may not be detectable by the scanning radar, thus inducing an underestimation of the total ash volume and mass. This problem, which is clearly visible in Figs. $1-2$ by looking at HVMI horizontal and vertical projections and is worse at larger distances, is a well known problem in radar meteorology and it is often overcome relying on the reconstruction of the Vertical Profile of Reflectivity (VPR) (Sauvageot, 1992; Marzano et al., 2004). An approximate way to approach the VPR problem is to project the measured reflectivity $Z_{\mathrm{Hm}}$, available at the lowest range bin, down to the terrain height at $z=z_{\mathrm{s}}$, assuming that the lowest detectable value is the major responsible of ash fallout deposited on the ground from the vertical column above a considered position. To some extent, this approach is similar to that adopted when estimating the total mass from satellite thermal-infrared radiometers when estimates of ash cloud top layers are extrapolated to ground (Wen and Rose, 1994; Yu 

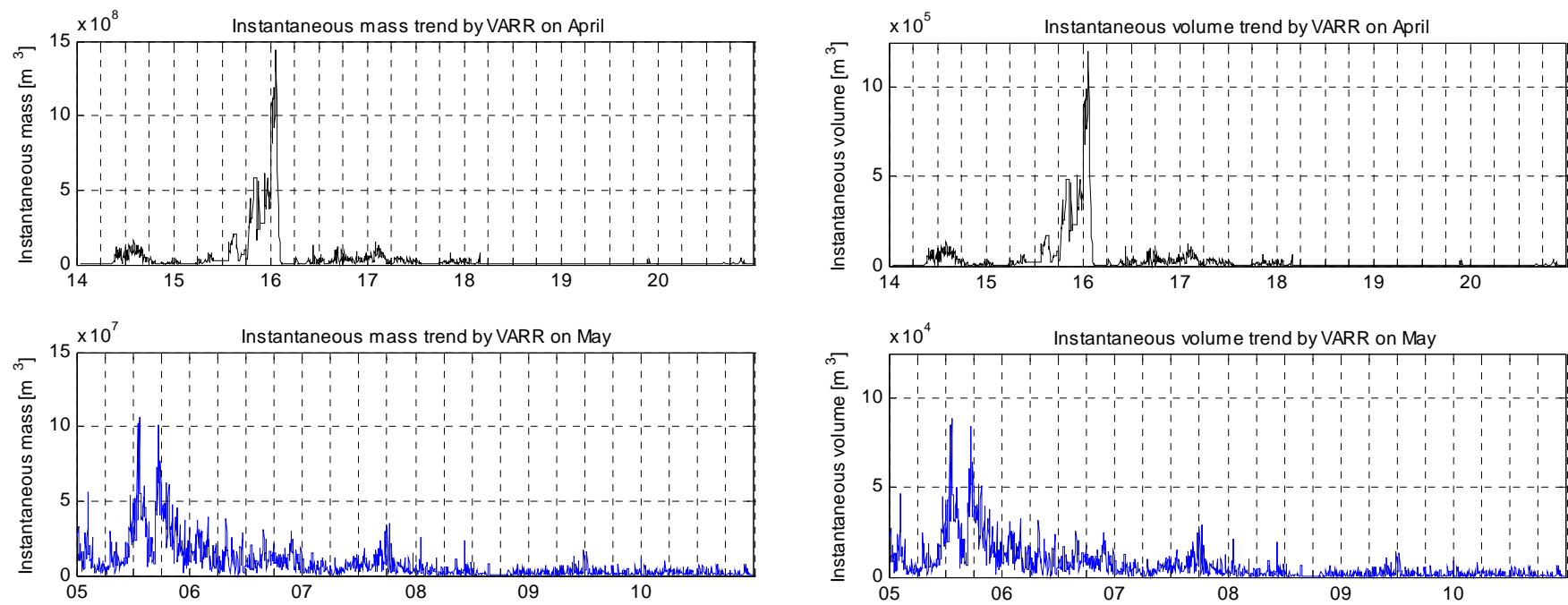

Fig. 3. Instantaneous mass (obtained from ash rate $R_{\mathrm{a}}$ estimated by VARR) versus time expressed in terms of scan days with reference to the eruptions on April (upper panel) and May (lower panel). The ticks on the $\mathrm{x}$-axis have a spacing equal to six hours. The scan sampling period is equal to $5 \mathrm{~min}$ so that the time series shows a time window of about $10020 \mathrm{~min}$ (equal to $167 \mathrm{~h}$ ) since the first available radar data at 01:00 UTC on 14 April 2010 with reference to the dataset of April and about $8630 \mathrm{~min}$ (equal to $143.8 \mathrm{~h}$ ) since the first available radar data at 00:10 UTC on 5 May 2010 with reference to the dataset of May.

et al., 2002). In both approaches we are neglecting the finite time interval that a radar resolution volume (bin) of ash takes to reach the ground (given an ash terminal velocity). Note that the latter, coupled with the horizontal transport effects, may cause a displacement between the radar measure and the actual ash deposition at the ground.

Using $V_{\mathrm{a}}(t)$, the instantaneous ash mass $M_{\mathrm{a}}(t)(\mathrm{kg})$, from each radar 3-D volume, is given by:

$M_{\mathrm{a}}(t) \equiv \int_{V_{\mathrm{a}}(t)} C_{\mathrm{a}}(\lambda, \phi, z ; t) d V=\rho_{\mathrm{a}} V_{\mathrm{a}}(t)$

where $\rho_{\mathrm{a}}\left(\mathrm{kg} \mathrm{m}^{-3}\right)$ is the ash density assumed to be constant and equal to about $1200 \mathrm{~kg} \mathrm{~m}^{-3}$. The temporal trend of the instantaneous total mass $M_{\mathrm{a}}(t)$, retrieved from VARR and defined in Eq. (7), is shown in Fig. 3 with reference to both available datasets on April and May 2010. The instantaneous volume temporal trends, obtained from Eq. (7), are shown in Fig. 4 for the same time windows as in Fig. 3.

These plots are useful to estimate the intensity of the volcanic eruption in near real-time mode. The scan sampling period is equal to $5 \mathrm{~min}$ so that the time series shows a time window of about $10020 \mathrm{~min}$ (equal to $167 \mathrm{~h}$ ) since the first available radar measurements at 01:00 UTC on 14 April 2010 with reference to the dataset of April and about $8630 \mathrm{~min}$ (equal to $143.8 \mathrm{~h}$ ) since the first available radar measurements at 00:10 UTC on 5 May 2010 with reference to the

Fig. 4. Instantaneous volume versus scan days, with input data from VARR algorithm with concentration threshold $\left(C_{\mathrm{a}}>\right.$ $10^{-6} \mathrm{~kg} \mathrm{~m}^{-3}$ ). In the upper panel, the trend with reference to April time window (since 01:00 UTC on 14 April 2010 till 23:55 UTC on 20 April 2010); in the lower panel, the trend with reference to May time window (since 00:10 UTC on 5 May 2010 till 23:55 UTC on 10 May 2010).

dataset of May. Both Figs. 3 and 4 shows that the eruption peak on April 2010 was at the beginning of the 16th day where ash mass up to $15 \cdot 10^{8} \mathrm{~kg}$ was estimated. During the May episode the most intense day was on 5 May with ash mass up to $8 \cdot 10^{7} \mathrm{~kg}$. It is interesting to note: (i) the intermittent and pulsed temporal character of the Eyjafjöll eruption, especially during the April volcanic activity; (ii) the abrupt decrease of erupted mass at the end of 16 April; (iii) the longer and gradually decrease tail of the May event which lasts more than 6 days.

The spatial distribution of the instantaneous maximum plume height $H_{\mathrm{a}}(\lambda, \varphi ; t)(\mathrm{km})$ can be then derived by using either a threshold $Z_{\mathrm{Hmth}}$ on the measured reflectivity $Z_{\mathrm{Hm}}(\lambda$, $\varphi, z ; t)$ or a threshold $C_{\text {ath }}$ on $C_{\mathrm{a}}(\lambda, \varphi, z ; t)$ as follows:

$H_{\mathrm{a}}(\lambda, \phi ; t) \equiv\left\{\begin{array}{l}\operatorname{Max}_{z}\left[z \mid Z_{\mathrm{Hm}}(\lambda, \phi, z ; t) \geq Z_{\mathrm{Hmth}}\right] \\ \operatorname{Max}_{z}\left[z \mid C_{\mathrm{a}}(\lambda, \phi, z ; t) \geq C_{\mathrm{ath}}\right]\end{array}\right.$

where $\operatorname{Max}_{z}$ is the maximum operator with respect to $z$. The two approaches do not necessarily provide the same result, as will be shown later, due to the different and independent adopted thresholds. The maximum height $H_{\mathrm{aM}}$ of $H_{\mathrm{a}}(\lambda, \varphi$; $t$ ) with respect to any $(\lambda, \varphi)$ in Eq. (9) is provided by:

$H_{\mathrm{aM}}(t) \equiv \operatorname{Max}_{\lambda, \phi}\left[H_{\mathrm{a}}(\lambda, \phi ; t)\right]$

where $\operatorname{Max}_{\lambda, \varphi}$ is the maximum operator with respect to $(\lambda$, $\varphi)$. The maximum height, $H_{\mathrm{aM}}$, can be also referred to the spatial sub-domain around the volcano vent. The analysis of the maximum plume height $H_{\mathrm{aM}}$ is both an important input 
parameter in a plenty of volcanological models which forecast the volcanic eruption intensity and the most useful quantity to aerial routes planning in the areas near the volcanic eruption (Stohl et al., 2010). Plinian and sub-Plinian explosive eruptions reach their neutral level (above this height the cloud stops its vertical growth and starts to spread radially) at the same altitude of modern commercial airplanes flight level (Sparks et al., 1997). The merging of local VAACs (Volcanic Ash Advisory Centres) information with the information about the plume height, estimated by meteorological forecast centres, can be very useful to produce more accurate and precise VA-SIGMET (Volcanic Ash SIGnificant METeorological event information) reports (Prata and Tupper, 2009).

The temporal evolution of the maximum plume height $H_{\mathrm{aM}}$, during a time interval from 01:00 UTC on 14 April 2010 till 23:55 UTC on 20 April 2010 and from 00:10 UTC on 5 May 2010 till 23:55 UTC on 10 May 2010 is shown in Fig. 5, with 5-min resolution. The two plots show the estimates of VARR algorithm with detection thresholds on concentration $\left(C_{\mathrm{a}}>10^{-3} \mathrm{~g} \mathrm{~m}^{3}\right)$ with reference to April (upper panel) and May (lower panel) eruptions. All the altitudes are scaled with reference to the Eyjafjöll height above sea level $(1666 \mathrm{~m})$. Figure 6 shows the same of Fig. 5, but by using Eq. (9) with a detection thresholds on reflectivity $\left(Z_{\mathrm{Hm}}>-6 \mathrm{dBZ}\right)$. The plume height estimation shows a certain variability, also due to the altitude discrete sampling of radar beams at given elevations. Indeed, the degraded radial resolution (about $2 \mathrm{~km}$ in our case) should not be confused with the minimum step for estimating $H_{\mathrm{a}}$ or $H_{\mathrm{aM}}$. The radar radial resolution coincides with the vertical resolution only for antenna zenithal pointing (or elevation angle equal to $90^{\circ}$ ). For low elevation angles, such as those of scanning weather radars, the vertical coordinate $z$ in Eq. (9) is resolved at a variable range-dependent resolution which, in our case, may be even less than few hundreds of meters. For both eruption periods the estimated maximum height is up to $10 \mathrm{~km}$, with a larger dynamical range of values for the April event than for the May event. It is worth noting that the temporal trend of $H_{\mathrm{aM}}(t)$ is not necessarily correlated with the estimated $M_{\mathrm{a}}(t)$.

The maximum plume height retrievals $H_{\mathrm{aM}}$, provided by weather radars, can be used as an input variable in models that compute the Eruption Discharge Rate (EDR), a useful parameter to mark the intensity of a volcanic eruption (Wilson, 1972; Sparks et al., 1997). The thermal energy of the erupted tephra is used to heat the air trapped within the eruption jet and causes convective phenomena that raise the eruptive column. When the EDR is known, it is possible to estimate the thickness of the ash layer that will settle on the ground according to a model widely used for eruption columns which produce strong plumes (Wilson et al., 1978). Adapting the Morton relation to the Eyjafjöll volcano eruption (Morton et al., 1952) and considering a basaltic magma the estimated EDR, indicated by $Q_{\mathrm{H}}(t)\left(\mathrm{m}^{3} \mathrm{~s}^{-1}\right)$, can be ob-
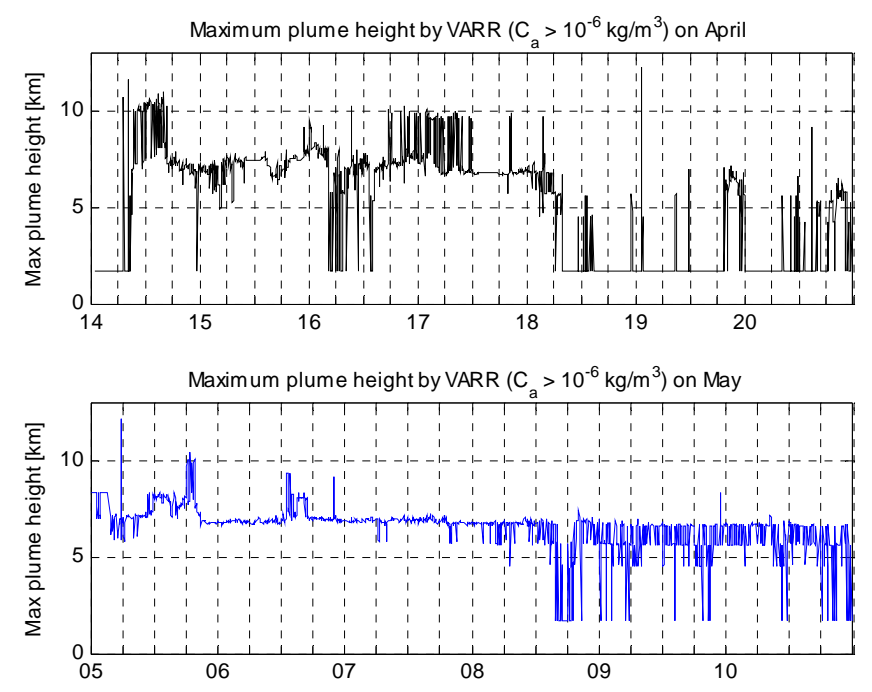

Fig. 5. Instantaneous maximum plume height versus scan days, with input data from VARR algorithm with concentration threshold $\left(C_{\mathrm{a}}>10^{-6} \mathrm{~kg} \mathrm{~m}^{3}\right)$. In the upper panel, the trend with reference to April time window (since 01:00 UTC on 14 April 2010 till 23:55 UTC on 20 April 2010); in the lower panel, the trend with reference to May time window (since 00:10 UTC on 5 May 2010 till 23:55 UTC on 10 May 2010).
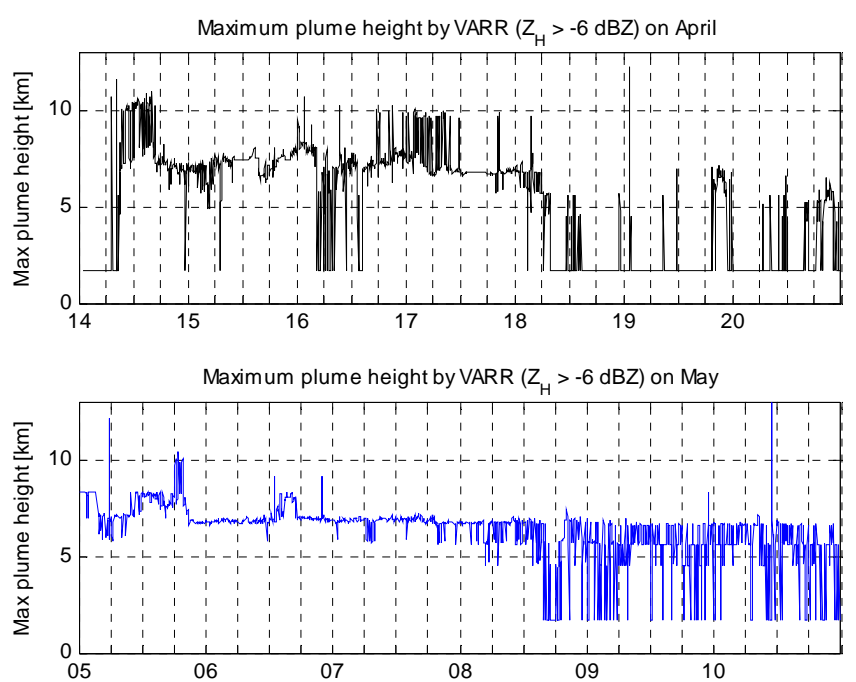

Fig. 6. Instantaneous maximum plume height versus scan days, with input data from VARR algorithm with reflectivity threshold $\left(Z_{\mathrm{H}}>-6 \mathrm{dBZ}\right)$. In the upper panel, the trend with reference to April time window (since 01:00 UTC on 14 April 2010 till 23:55 UTC on 20 April 2010); in the lower panel, the trend with reference to May time window (since 00:10 UTC on 5 May 2010 till 23:55 UTC on 10 May 2010).

tained from maximum plume height through the following approximate relation (Oddsson et al., 2009; Marzano et al., 2011a): 

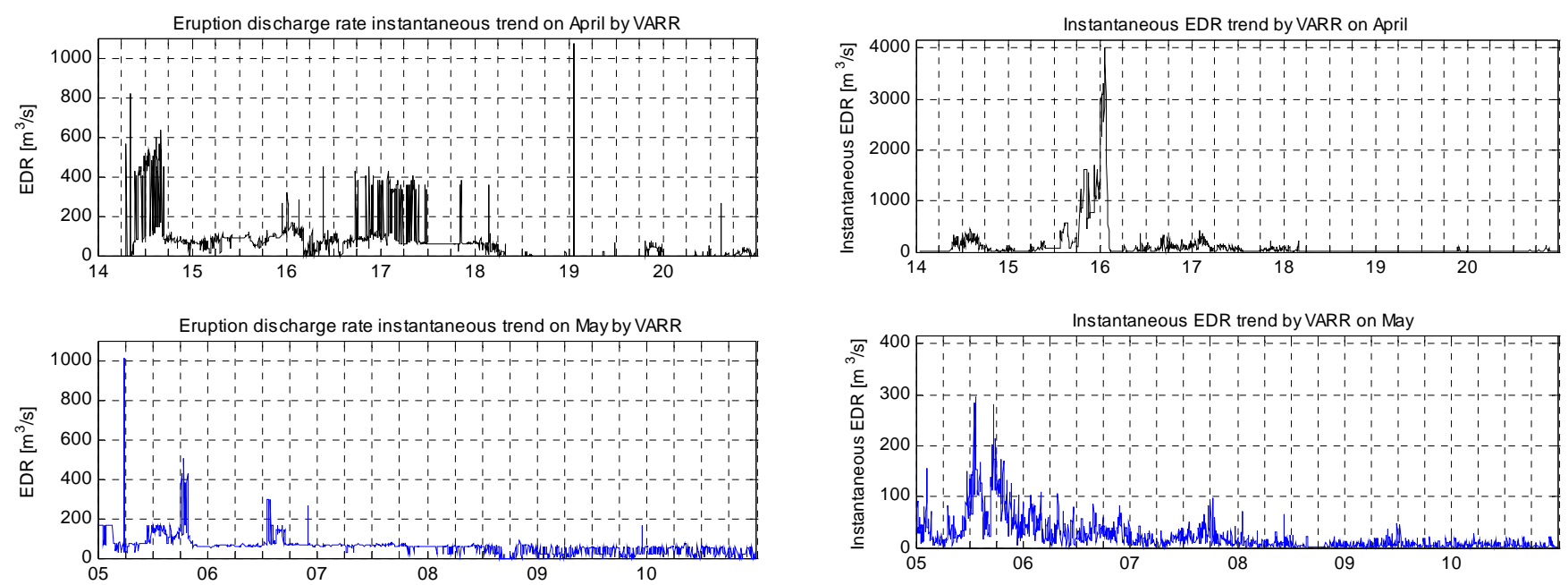

Fig. 7. Instantaneous Eruption Discharge Rate (EDR), obtained from the maximum plume height versus scan number, with input data from VARR algorithm with concentration threshold $\left(C_{\mathrm{a}}>\right.$ $\left.10^{-6} \mathrm{~kg} \mathrm{~m}^{-3}\right)$. In the upper panel, the trend with reference to April time window (since 01:00 UTC on 14 April 2010 till 23:55 UTC on 20 April 2010); in the lower panel, the trend with reference to May time window (since 00:10 UTC on 5 May 2010 till 23:55 UTC on 10 May 2010). Mean EDR values are also quoted in both panels.

$Q_{\mathrm{H}}(t) \cong 0.085\left[H_{\mathrm{aM}}(t)\right]^{4}$

The Eq. (11) shows that EDR is linked to the fourth power of the height and so small fluctuations of the height cause large variations of the EDR. EDR temporal trends, obtained from VARR using Eq. (11) with a threshold on ash concentration $C_{\mathrm{a}}$, are shown for both April and May time windows in Fig. 7. The power-law dependence of $Q_{\mathrm{H}}$ on the maximum plume height tends to amplify the EDR peaks. This figure suggests that the larger EDR is on 14 April and across 17 April, with an isolated peak on 19 April 2010. The behaviour on May is more uniform with some relative maxima on 5 and 6 May 2010.

The EDR can be also directly evaluated from the temporal trend of the estimated ash volume $V_{\mathrm{a}}(t)$. The radar-derived EDR $Q_{V}(t)\left(\mathrm{m}^{3} \mathrm{~s}^{-1}\right)$ is evaluated through the ratio between the temporal average instantaneous volume and the sampling interval $\Delta t$ :

$Q_{V}(t)=\frac{\overline{V_{\mathrm{a}}(t)}}{\Delta t}=\frac{1}{\Delta t}\left(\frac{1}{\Delta t} \int_{0}^{\Delta t} V_{\mathrm{a}}(t) d t\right) \cong \frac{V_{\mathrm{a}}\left(t_{i}\right)}{\Delta t_{\mathrm{s}}}$

where $t_{i}$ is the $\mathrm{i}$-th time step within the sampling period $\Delta t_{\mathrm{s}}$ where $V_{\mathrm{a}}$ is assumed constant in order to obtain the approximation of $Q_{V}(t)$ in Eq. (12). Similarly to Fig. 7, Fig. 8 shows the estimated $Q_{V}(t)$ using Eq. (12) for both the April and May periods. The temporal trend of $Q_{V}(t)$ is quite different from that of $Q_{\mathrm{H}}(t)$, shown in Fig. 7. The reason of this difference may be attributed to the fact that $Q_{\mathrm{H}}$ takes into account only the ash cloud altitude, whereas $Q_{V}$ is related to

Fig. 8. Same as in Fig. 7, but for EDR derived from the estimated instantaneous ash volume.

the erupted 3-D volume. Indeed, the estimate of $Q_{V}(t)$ is affected by the observation geometrical limits which reduce the detected $V_{\mathrm{a}}(t)$, partially reconstructed through the VPR approach. The estimate of EDR through Eq. (12) evidences that the strongest peak is around the end of 16 April 2010 with EDR up to $4000 \mathrm{~m}^{3} \mathrm{~s}^{-1}$, whereas the May event shows peaks less than $300 \mathrm{~m}^{3} \mathrm{~s}^{-1}$ with a more intense activity on 5 May 2010.

\subsection{Retrieval spatial maps}

The deposited ash at ground during the whole event can be estimated from the retrieved ash fall rate $R_{\mathrm{a}}(\lambda, \varphi, z, t)$. By performing a VPR reconstruction, as indicated before, and indicating with $R_{\mathrm{a}}\left(\lambda, \varphi, z=z_{\mathrm{s}}, t\right)$ the ash fall rate at the surface height, $z_{\mathrm{s}}$, the spatial distribution of the radar-derived deposited tephra density or loading $D_{\mathrm{a}}(\lambda, \varphi)\left(\mathrm{kg} \mathrm{m}^{-2}\right)$ is obtained from:

$D_{\mathrm{a}}(\lambda, \phi) \equiv \int_{t_{\mathrm{i}}}^{t_{\mathrm{f}}} R_{\mathrm{a}}\left(\lambda, \phi, z=z_{\mathrm{s}} ; t\right) d t$

where $t_{\mathrm{i}}$ and $t_{\mathrm{f}}$ are the initial and final time steps of the volcanic eruption. The total space-time deposited tephra mass $M_{\mathrm{aT}}(\mathrm{kg})$ from radar measurements can be evaluated by using:

$M_{\mathrm{aT}}=\int_{D_{\mathrm{a}} \geq D_{\min }} D_{\mathrm{a}}(\lambda, \phi) d S$

where $D_{\min }$ is a threshold value of $D_{\mathrm{a}}$. The radar-derived total ash volume may be estimated by $V_{\mathrm{aT}}=M_{\mathrm{aT}} / \rho_{\mathrm{a}}$. In order to convert the deposited ash loading $D_{\mathrm{a}}$ into deposited ash depth $d_{\mathrm{a}}(\mathrm{m})$, it holds $d_{\mathrm{a}}=D_{\mathrm{a}} / \rho_{\mathrm{a}}$. Note that $M_{\mathrm{aT}}$ could be estimated by integrating Eq. (8) as well, but in that case no VPR reconstruction would be performed. 
Ground accumulated ash mass distrubution $\left[\mathrm{kg} / \mathrm{m}^{2}\right]$ every 12 hours (from 00:00 UTC on April 15, 2010 to 23:55 UTC on April 18, 2010)
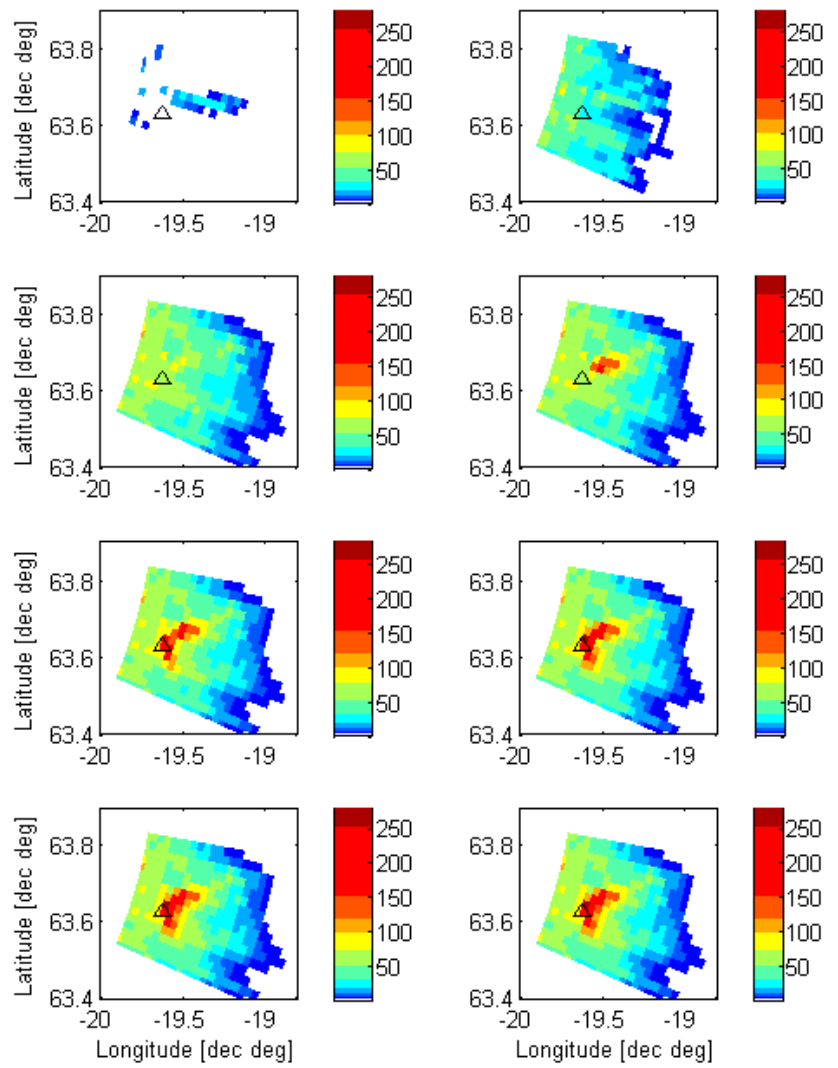

Fig. 9. Distal fallout spatial maps retrieved by VARR. The distributions show the accumulated ash mass at the ground every twelve hours (from left to right, from top panel to bottom) since 00:00 UTC on 15 April 2010 till 23:55 UTC on 18 April 2010. The black edged triangle is centred in the exact position of the Eyjafjöll volcano, whereas colorbars are scaled to match the different dynamic range of the distributions.

Deposited ash mass $D_{\mathrm{a}}(x, y)$, evaluated through Eq. (12) in terms of distal spatial maps derived from radar, can be an appealing way to monitor the evolution of a volcanic eruption in terms of ash fallout as shown in Fig. 9 and Fig. 10. The figures show the accumulated ground mass distribution of the ash within geo-referenced spatial maps, thus providing a useful instrument to gather information about the time progression of the ash fallout. These results indicate that the April volcanic eruption ejected a bigger amount of tephra than that due to the May volcanic eruption. In order to quantitatively confirm previous considerations, Tables 2 and 3 show the total ash mass and total volume values for the 14-20 April 2010 and and the 5-10 May 2010 eruption period, respectively, obtained from radar-derived ashfall rate $R_{\mathrm{a}}$ by selecting a fall velocity values $a_{v}$ and $b_{v}$, derived from the Harris and Rose (1983) ash fallout (HAF) data and the Wilson (1972) ash fallout (WAF) data. Sensitivity of total mass volume to the standard deviation of estimated ashfall rate is also shown.
Ground accumulated ash mass distrubution $\left[\mathrm{kg} / \mathrm{m}^{2}\right.$ ] every 12 hours (from 00:00 UTC on May 05, 2010 to 23:55 UTC on May 08, 2010)
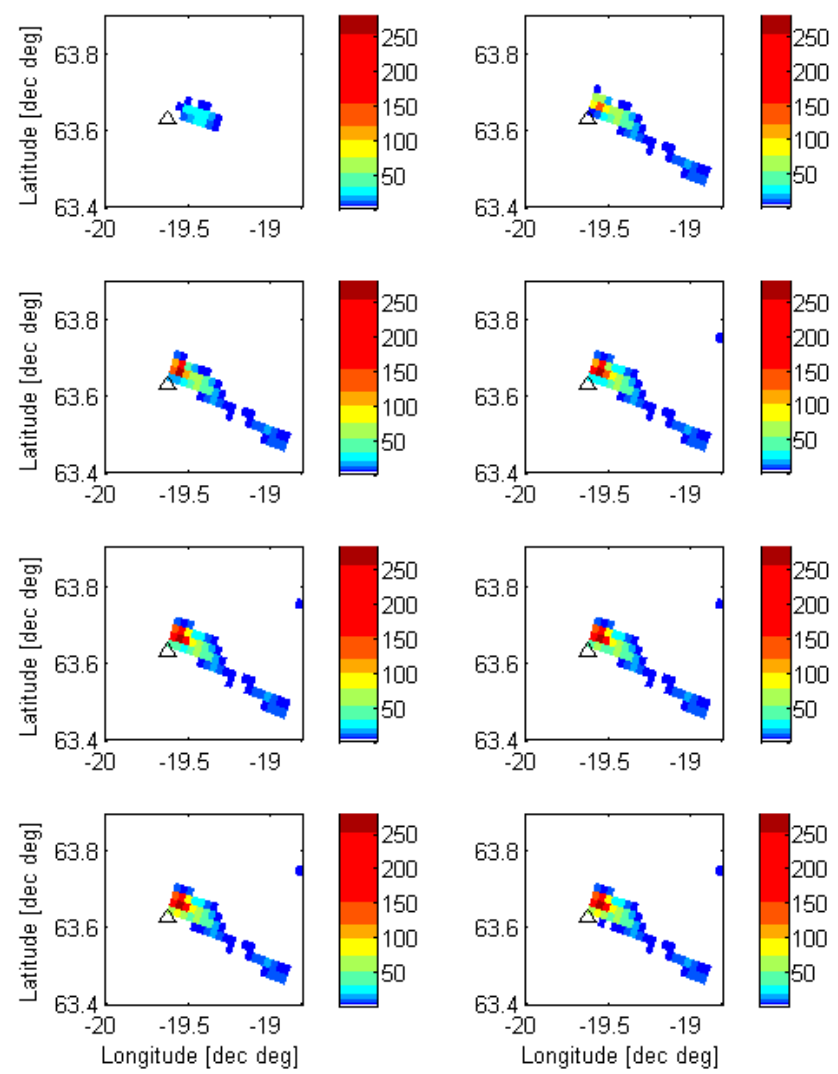

Fig. 10. Distal fallout spatial maps retrieved by VARR. The distributions show the accumulated ash mass at the ground every twelve hours (from left to right, from top panel to bottom) since 00:00 UTC on 5 May 2010 till 23:55 UTC on 8 May 2010. The black edged triangle is centred in the exact position of the Eyjafjöll volcano, whereas colorbars are scaled to match the different dynamic range of the distributions.

The sensitivity to the ash category is quite relevant in the radar mass estimation. The latter consideration is confirmed by Figs. 11 and 12 which, respectively, show the histogram of the 9 radar-estimated ash categories by VARR ash classification (see Table 1) during the whole eruption event and the occurrence of a given ash concentration (small, moderate and intense) within each ash class (fine ash, coarse ash and lapilli). With reference to the whole eruption, the total number of available resolution volumes was 6200376 for April and 5340244 for May, but they have been reduced, respectively, to 121442 and 30423 considering only ash-containing volumes (i.e. excluding all resolution volumes with ash class label value equal to 0 ). The figures respectively show that, with reference to April, almost $62 \%$ of detected ash belongs to coarse ash with moderate concentration $(c=5)$, whereas no bins were labeled as fine ash with small concentration $(c=1)$ nor lapilli with intense concentration $(c=9)$. For 
the observations in May, above the $85 \%$ of total detected ash belongs to coarse ash with small and moderate concentration ( $c=4$ and $c=5$ ), whereas there is a low occurence of lapilli (limited to small concentration, with $c=7$ ).
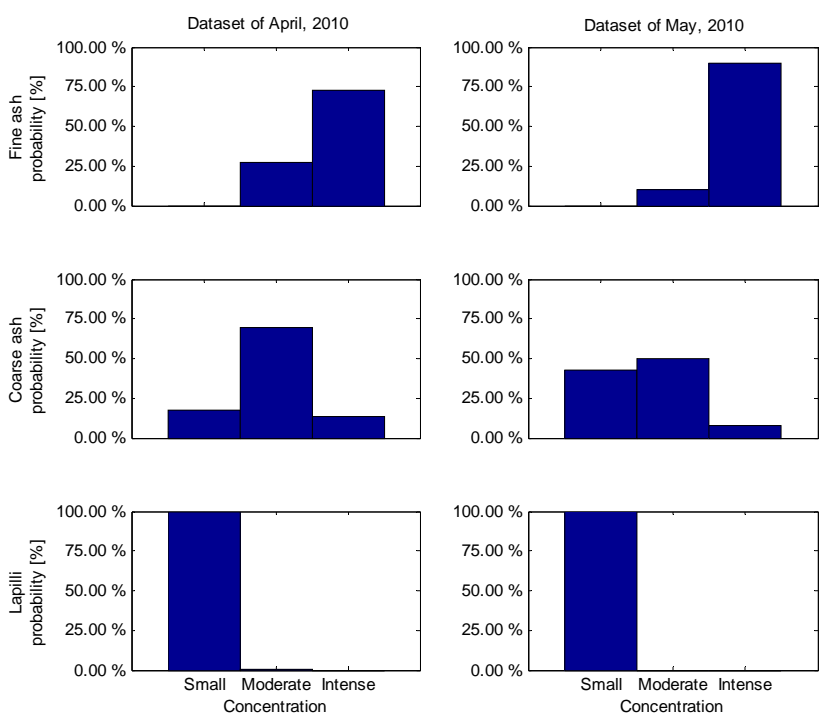

Fig. 11. Histograms showing the probability of a given ash concentration value, with respect to the total number of labels attached to the processed unit radar volumes (121 442 for April and 30423 for May) and to the ash class. The latter are displayed on panels from top to bottom as fine ash, coarse ash and lapilli. Only significant volumes have been considered, with reference to the whole eruption since 01:00 UTC on 14 April 2010 till 23:55 UTC on 20 April 2010 (left panels) and since 00:10 UTC on 5 May 2010 till 23:55 UTC on 10 May 2010 (right panels). Note that very few lapilli were detected during the eruptions.

Coarse ash particles, as expected, are the most probable with a lower occurrence of finer particles around the volcanic caldera (except fine ash with small concentration). On the contrary, lapilli are found in regions closer to the volcanic vent due to ballistic ejections (note that both on April and May virtually no lapilli have been detected). The occurrences are quite similar in both time windows as shown in Fig. 11; coarse ash with small concentration percentage occurrence is higher on May, whereas the fine ash distribution with respect to ash concentration is very similar. Lapilli occurrence is very low on both eruptions. There are two reasons to explain the difference in the total number of ash containing volumes between April and May dataset. First of all, the April data refer to one week, whereas the May ones are provided with reference to six days; moreover, the May eruption has been less powerful than the peak of the volcanic activity reached during the month of April and so the number of volumes is not a simple scaling between the two cases of study.
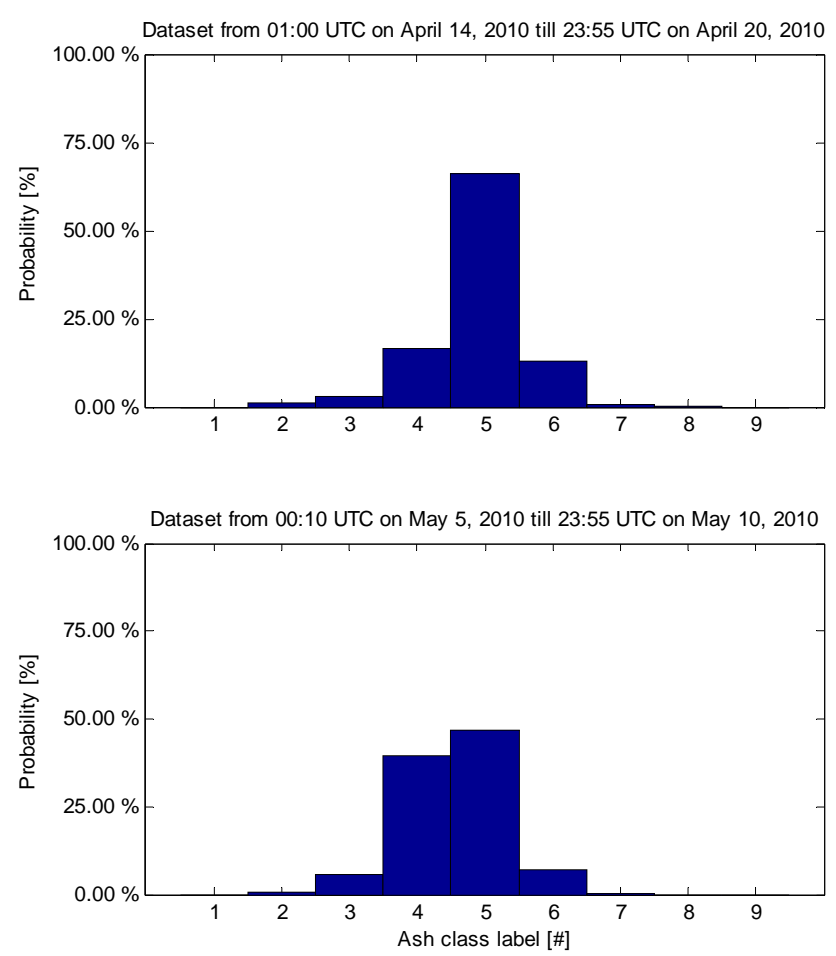

Fig. 12. Histogram showing the probability of a given ash class label value, with respect to the total number of labels attached to the processed unit radar volumes (121442 for April and 30423 for May). Only significant volumes have been considered, with reference to the whole eruption since 01:00 UTC on 14 April 2010 till 23:55 UTC on 20 April 2010 and since 00:10 UTC on 5 May 2010 till 23:55 UTC on 10 May 2010. Both on April and May, higher occurrence corresponds to coarse ash with moderate concentration, whereas lapilli and fine ash with small concentration have been virtually not observed during the eruption.

\section{Conclusions}

The Eyjafjöll explosive volcanic eruptions, occurred on April and May 2010, have been analyzed and quantitatively interpreted by using ground-based weather radar data and VARR inversion technique. The latter has been applied to the Keflavík C-band weather radar, located at a distance of about $155 \mathrm{~km}$ from the volcano vent. The VARR methodology has been summarized and applied to available radar time series to estimate the plume maximum height, ash particle category, ash volume, ash fallout and ash concentration every five minutes. Estimates of the discharge rate of eruption, based on the retrieved ash plume top height, have been also provided together with the deposited ash at ground.

The possibility of monitoring $24 \mathrm{~h}$ a day, in all weather conditions, at a fairly high spatial resolution and every few minutes after the eruption is the major advantage of using ground-based microwave radar systems. The latter can be crucial systems to monitor the "near-source" eruption from its early-stage near the volcano vent, dominated by coarse 
Table 2. Total mass and total volume values for the 14-20 April 2010 eruption period, obtained from radar-derived ashfall rate $R_{\mathrm{a}}$ by selecting a fall velocity values $a_{\mathrm{v}}$ and $b_{\mathrm{v}}$, derived from the Harris and Rose (1983) ash fallout (HAF) data and the Wilson (1972) ash fallout (WAF) data. Sensitivity of total mass volume to the standard deviation of estimated ashfall rate, indicated by $\sigma\left(R_{\mathrm{a}}\right)$, is also shown.

\begin{tabular}{lccc}
\hline Source & Fallout model & Total mass $(\mathrm{kg})$ & Total volume $\left(\mathrm{m}^{3}\right)$ \\
\hline VARR using $R_{\mathrm{a}}-\sigma\left(R_{\mathrm{a}}\right)$ & HAF & $8.2455 \times 10^{10}$ & $6.8713 \times 10^{7}$ \\
VARR using $R_{\mathrm{a}}$ & $\mathrm{HAF}$ & $8.5193 \times 10^{10}$ & $7.0994 \times 10^{7}$ \\
VARR using $R_{\mathrm{a}}+\sigma\left(R_{\mathrm{a}}\right)$ & $\mathrm{HAF}$ & $8.7734 \times 10^{10}$ & $7.3112 \times 10^{7}$ \\
VARR using $R_{\mathrm{a}}-\sigma\left(R_{\mathrm{a}}\right)$ & WAF & $6.7303 \times 10^{10}$ & $5.6086 \times 10^{7}$ \\
VARR using $R_{\mathrm{a}}$ & WAF & $7.0193 \times 10^{10}$ & $5.8494 \times 10^{7}$ \\
VARR using $R_{\mathrm{a}}+\sigma\left(R_{\mathrm{a}}\right)$ & WAF & $6.3656 \times 10^{10}$ & $5.3046 \times 10^{7}$ \\
\hline
\end{tabular}

Table 3. Same as in Table 2, but for the 5-10 May 2010 eruption period.

\begin{tabular}{lccc}
\hline Source & Fallout model & Total mass $(\mathrm{kg})$ & Total volume $\left(\mathrm{m}^{3}\right)$ \\
\hline VARR using $R_{\mathrm{a}}-\sigma\left(R_{\mathrm{a}}\right)$ & $\mathrm{HAF}$ & $1.3901 \times 10^{10}$ & $1.1584 \times 10^{7}$ \\
VARR using $R_{\mathrm{a}}$ & $\mathrm{HAF}$ & $1.6693 \times 10^{10}$ & $1.3911 \times 10^{7}$ \\
VARR using $R_{\mathrm{a}}+\sigma\left(R_{\mathrm{a}}\right)$ & $\mathrm{HAF}$ & $1.2056 \times 10^{10}$ & $1.0047 \times 10^{7}$ \\
VARR using $R_{\mathrm{a}}-\sigma\left(R_{\mathrm{a}}\right)$ & WAF & $1.0813 \times 10^{10}$ & $9.0107 \times 10^{6}$ \\
VARR using $R_{\mathrm{a}}$ & WAF & $1.2789 \times 10^{10}$ & $1.0658 \times 10^{7}$ \\
VARR using $R_{\mathrm{a}}+\sigma\left(R_{\mathrm{a}}\right)$ & WAF & $8.7011 \times 10^{9}$ & $7.2509 \times 10^{6}$ \\
\hline
\end{tabular}

ash and blocks, to ash-dispersion stage up to hundreds of kilometers, dominated by transport and evolution of coarse and fine ash particles. For distances larger than about several tens of kilometers fine ash might become "invisible" to the radar. In this respect, radar observations can be complementary to satellite, lidar and aircraft observations. Moreover, radar-based products can be used to initialize dispersion model inputs. Due to logistics and space-time variability of the volcanic eruptions, a suggested optimal radar system to detect ash cloud could be a portable X-band weather Doppler polarimetric radar (Marzano et al., 2011b). This radar system may satisfy technological, economical and new scientific requirements to detect ash cloud. The sitting of the observation system which is a problematic tradeoff for a fixed radar system (as the volcano itself may cause a beam obstruction and the ash plume may move in unknown directions), can be easily solved by resorting to portable systems.

Further work is needed to assess the VARR potential using experimental campaign data. Future investigations should be devoted to the analysis of the impact of ash aggregates on microwave radar reflectivity and on the validation of radar estimates of ash amount with ground measurements where available. The last task is not an easy one as the ash fall is dominated by wind advection and by several complicated microphysical processes. This means that what is retrieved within an ash cloud may be not representative of what was collected at ground level in a given area. Spatial integration of ground-collected and radar-retrieved ash amounts may be considered to carry out a meaningful comparison. Preliminary results for the Grímsvötn case study show that the radarbased tephra ash mass estimates retrievals compare well with the deposited ash blanket estimated from in situ ground sampling within the volcanic surrounding area (Marzano et al., 2011a).

Acknowledgements. We are very grateful to B. Pálmason, H. Pétursson and S. Karlsdóttir (IMO, Iceland) for providing C-band radar data and useful suggestions on data processing. The contribution and stimulus of B. De Bernardinis (ISPRA, Italy and formerly DPC, Italy) and G. Vulpiani (DPC, Italy) is gratefully acknowledged. We also wish to thank S. Pavone and S. Barbieri (Sapienza University, Italy) who contributed to the development of the VARR software and the comparison analysis. This work has been partially funded by the Italian Department of Civil Protection (DPC, Rome, Italy) under the project IDRA and by the Sapienza University of Rome (Italy).

Edited by: F. Prata

\section{References}

Ansmann, A., Tesche, M., Gro, S., Freudenthaler, V., Seifert, P., Hiebsch, A., Schmidt, J., Wandinger, U., Mattis, I., Müller, D., and Wiegner, M.: The 16 april 2010 major volcanic ash plume over central Europe: EARLINET lidar and AERONET photometer observations at Leipzig and Munich, Germany, Geophys. Res. Lett., L13810, doi:10.1029/2010GL043809, 2010. 
Bennett, A. J., Odams, P., Edwards, D., and Arason, P: Monitoring of lightning from the April-May 2010 Eyjafjallajökull volcanic eruption using a very low frequency lightning location network, Environ. Res. Lett. 5, 44013-44022, 2010.

Bonadonna, C., Phillips, J. C., and Houghton, B. F.: Modeling tephra sedimentation from a Ruapehu weak plume eruption, J. Geophys. Res., 110, B08209, doi:10.1029/2004JB003515, 2005.

Costa, A., Macedonio, G., and Folch, A.: A three dimensional Eulerian model for transport and deposition of volcanic ashes, Earth Planet. Sci. Lett., 241, 634-647, 2006.

Duggen, S., Olgun, N., Croot, P., Hoffmann, L., Dietze, H., Delmelle, P., and Teschner, C.: The role of airborne volcanic ash for the surface ocean biogeochemical iron-cycle: a review, Biogeosciences, 7, 827-844, doi:10.5194/bg-7-827-2010, 2010.

Durant, A. J., Bonadonna, C., and Horwell, C. J.: Atmospheric and environmental impacts of volcanic particulates, Elements, 6 , 235-240, 2010.

Flentje, H., Claude, H., Elste, T., Gilge, S., Köhler, U., PlassDülmer, C., Steinbrecht, W., Thomas, W., Werner, A., and Fricke, W.: The Eyjafjallajökull eruption in April 2010 Ü- detection of volcanic plume using in-situ measurements, ozone sondes and lidar-ceilometer profiles, Atmos. Chem. Phys., 10, 1008510092, doi:10.5194/acp-10-10085-2010, 2010.

Gangale, G., Prata, A. J., and Clarisse, L.: The infrared spectral signature of volcanic ash determined from high-spectral resolution satellite measurements, Remote Sens. Environ., 114(2), 414-425, 2010.

Gasteiger, J., Groß, S., Freudenthaler, V., and Wiegner, M.: Volcanic ash from Iceland over Munich: mass concentration retrieved from ground-based remote sensing measurements, Atmos. Chem. Phys., 11, 2209-2223, doi:10.5194/acp-11-22092011, 2011.

Gertisser, R.: Eyjafjallajökull volcano causes widespread disruption to European air traffic, Geol. Today, 26, 94-95, 2010.

Gouhier, M. and Donnadieu, F.: Mass estimations of ejecta from Strombolian explosions by inversion of Doppler radar measurements, J. Geophys. Res., 113, B10202, doi:10.1029/2007JB005383, 2008.

Graf, H.-F., Herzog, M., Oberhuber, J. M., and Textor, C.: Effect of environmental conditions on volcanic plume rise, J. Geophys. Res., 104, 20, 24309-24320, 1999.

Guðmundsson, M. T., Pedersen, R., Vogfjörð, K., Thorbjarnardóttir, B., Jakobsdóttir, S., and Roberts, M. J.: Eruptions of Eyjafjallajökull Volcano, Iceland, EOS, 91, 190-191, 2010.

Harris, D. M. and Rose, W. I.: Estimating particle sizes, concentrations and total mass of ash in volcanic clouds using weather radar, J. Geophys. Res., 88, 10969-10983, 1983.

Kahn, R. A., Li, W.-H., Moroney, C., Diner, D. J., Martonchik, J. V., and Fishbein, E.: Aerosol source plume physical characteristics from space-based multiangle imaging, J. Geophys. Res., 112, D11205, doi:10.1029/2006JD007647, 2007.

Lacasse, C., Karlsdóttir, S., Larsen, G., Soosalu, H., Rose, W. I., and Ernst, G. G. J.: Weather radar observations of the Hekla 2000 eruption cloud, Iceland, Bull. Volcanol., 66, 457-473, 2004.

Larsen, G., Guðdmundsson, M. T., and Björnsson, H.: Eight centuries of periodic volcanism at the center of the Iceland hotspot revealed by glacier tephrostratigraphy, Geology, 26(10), 943946, 1998.

Madonna, F., Amodeo, A., D’Amico, G., Mona, L., and Pap- palardo, G.: Observation of non-spherical ultragiant aerosol using a microwave radar, Geophys. Res. Lett., 37, L21814, doi:10.1029/2010GL044999, 2010.

Marzano, F. S., Picciotti E., and Vulpiani, G.: Rain field and reflectivity vertical profile reconstruction from C-band radar volumetric data, IEEE T. Geosci. Remote, 42(4), 1033-1046, 2004.

Marzano, F. S., Vulpiani, G., and Rose, W. I.: Microphysical characterization of microwave radar reflectivity due to volcanic ash clouds, IEEE T. Geosci. Remote, 44, 313-327, 2006 a.

Marzano, F. S., Barbieri, S., Vulpiani, G., and Rose, W. I.: Volcanic ash cloud retrieval by ground-based microwave weather radar, IEEE T. Geosci. Remote, 44, 3235-3246, $2006 \mathrm{~b}$.

Marzano, F. S., Marchiotto, S., Barbieri, S., Textor, C., and Schneider, D.: Model-based weather radar remote sensing of explosive volcanic ash eruption, IEEE T. Geosci. Remote, 48, 3591-3607, 2010a.

Marzano, F. S., Barbieri, S., Picciotti, E., and Karlsdóttir, S.: Monitoring subglacial volcanic eruption using ground-based C-band radar imagery, IEEE T. Geosci. Remote, 48, 403-414, 2010b.

Marzano, F. S., Lamantea, M., Montopoli, M., Oddsson, B., and Guðmundsson, M. T.: Validating subglacial volcanic eruption using ground-based C-band radar imagery, IEEE T. Geosci. Remote, in press, 2011a.

Marzano, F. S., Picciotti, E., Montopoli, M., and Vulpiani, G.: Synthetic signatures of volcanic ash cloud particles from Xband dual-polarization radar, IEEE T. Geosci. Remote, 99, 1-19, 2011b.

McCarthy, E. B., Bluth, G. J. S., Watson, I. M. and Tupper, A.: Detection and analysis of the volcanic clouds associated with the 18 and 28 August 2000 eruptions of Miyakejima volcano, Jap. Int. J. Remote Sens., 29(22), 6597-6620, 2008.

Mona, L., Amodeo, A., Boselli, A., Cornacchia, C., D’Amico, G., Giunta, A., Madonna, F., and Pappalardo, G.: Observations of the Eyjafjallajökull eruption's plume at Potenza EARLINET station, Geophys. Res. Abs., 12, EGU2010, 15747, 2010.

Morton, B. R., Geoffrey Taylor, F. R. S., and Turner, J.: Turbulent gravitational convection from maintained and instantaneous sources, Proceedings of the Royal Society of London. Series A, Mathematical and Physical Sciences, A234, 1-23, 1956.

Oddsson, B., Guðdmundsson, M. T., Larsen, G., and Karlsdóttir, S.: Grímsvötn 2004: Weather radar records and plume transport models applied to a phreatomagmatic basaltic eruption, Proc. IAVCEI (International Association of Volcanology and Chemistry of the Earth's Interior 2008, Reykjavík (Iceland), 18-24 August 2008 .

Pavolonis, M. J., Wayne, F. F., Heidinger, A. K., and Gallina, G. M.: A daytime complement to the reverse absorption technique for improved automated detection of volcanic ash, J. Atmos. Ocea. Technol., 23, 1422-1444, 2006.

Pedersen, R. and Sigmundsson, F.: Temporal development of the 1999 intrusive episode in the Eyjafjallajökull volcano, Iceland, derived from InSAR images, Bull Volcanol., 68, 377-393, doi:10.1007/s00445-005-0020-y, 2006

Petersen, G. N.: A short meteorological overview of the Eyjafjallajökull eruption 14 April-23 May 2010, Weather, 65, 203-207, 2010.

Pietruczuk, A., Krzyscin, J. W., Jaroslawski, J., Podgorski, J., P., Sobolewski, and Wink, J.: Eyjafjallajökull volcano ash observed over Belsk (52 $\mathrm{N}, 21^{\circ}$ E) Poland, in April 2010, Int. J. Remote 
Sens., 31, 3981-3986, 2010.

Prata, A. J. and Tupper, A.: Aviation hazards from volcanoes: the state of the science, Nat. Hazards, 51, 239-244, 2009.

Robock, A.: Volcanic eruptions and climate, Rev. Geophys., 38, 191-219, 2000.

Rose, W. J. and Durant, A. J.: Fine ash content of explosive eruptions, J. Volcanol. Geoth. Res., 186, 32-39, 2009.

Sauvageot H.: Radar meteorology, Artech House, Boston (MA), 1992.

Schumann, U., Weinzierl, B., Reitebuch, O., Schlager, H., Minikin, A., Forster, C., Baumann, R., Sailer, T., Graf, K., Mannstein, H., Voigt, C., Rahm, S., Simmet, R., Scheibe, M., Lichtenstern, M., Stock, P., Rüba, H., Schäuble, D., Tafferner, A., Rautenhaus, M., Gerz, T., Ziereis, H., Krautstrunk, M., Mallaun, C., Gayet, J.F., Lieke, K., Kandler, K., Ebert, M., Weinbruch, S., Stohl, A., Gasteiger, J., GroSS, S., Freudenthaler, V., Wiegner, M., Ansmann, A., Tesche, M., Olafsson, H., and Sturm, K.: Airborne observations of the Eyjafjalla volcano ash cloud over Europe during air space closure in April and May 2010, Atmos. Chem. Phys., 11, 2245-2279, doi:10.5194/acp-11-2245-2011, 2011.

Sparks, R.: The dimensions and dynamics of volcanic eruption columns. Bull. Volcanol., 48, 3-15, 1986.

Sparks, R. S. J., Bursik, M. I., Carey, S. N., Gilbert, J. S., Glaze, L., Sigurdsson, H., and Woods, A. W.: Volcanic Plumes. New York: Wiley, 1997.

Stohl, A., Hittenberger, M., and Wotawa, G.: Validation of the Lagrangian particle dispersion model FLEXPART against large scale tracer experiment data, Atmos. Environ., 32, 4245-4264, 1998.
Stohl, A., Prata, A. J., Eckhardt, S., Clarisse, L., Durant, A., Henne, S., Kristiansen, N. I., Minikin, A., Schumann, U., Seibert, P., Stebel, K., Thomas, H. E., Thorsteinsson, T., Tørseth, K., and Weinzierl, B.: Determination of time- and height-resolved volcanic ash emissions and their use for quantitative ash dispersion modeling: the 2010 Eyjafjallajökull eruption, Atmos. Chem. Phys., 11, 4333-4351, doi:10.5194/acp-11-4333-2011, 2011.

Thordarson, T. and Larsen, G.: Volcanism in Iceland in historical time: Volcano types, eruption styles and eruptive history, J. Geodynamics, 43(1), 118-152, 2007.

Yu, T., Rose, W. I. and Prata, A. J.: Atmospheric correction for satellite based volcanic ash mapping and retrievals using splitwindow IR data from GOES and AVHRR, J. Geophys. Res., 107(D16), 4311, doi:10.1029/2001JD000706, 2002.

Wen, S. and Rose, W. I.: Retrieval of sizes and total masses of particles in volcanic clouds using AVHRR bands 4 and 5, J. Geophys. Res., 99, 5421-5431, 1994.

Wilson, L:, Explosive volcanic eruptions - Part II: The atmospheric trajectories of pyroclasts, Geophys. J. R. Astron. Soc., 30(2), 381-392, 1972.

Wilson, L., Sparks, R. S. J., Huang, T. C., and Watkins, N. D.: The control of volcanic column heights by eruption energetics and dynamics, J. Geophys. Res., 83(83), 1829-1836, 1978.

Zehner, C.: Editor: Monitoring Volcanic Ash from Space. Proceedings of the ESA-EUMETSAT workshop on the 14 April to 23 May 2010 eruption at the Eyjafjoll volcano, South Iceland. Frascati, Italy, ESA-Publication STM-280. doi:10.5270/atmch10-01, 26-27 May 2010. 